\title{
Developing the surface layer parameters of road-building and mining machines
}

\author{
V. Gorshkov ${ }^{1}, S$. Maksimov ${ }^{1}$, and Aleksandr Pushkaryov ${ }^{1, *}$ \\ ${ }^{1}$ Saint Petersburg State University of Architecture and Civil Engineering, Saint Petersburg,Russia
}

\begin{abstract}
The article is intended for specialists in the field of restoring the parts of road-building and mining equipment. Information is given on the use of shot blasting to form a high-quality surface for parts of roadbuilding and mining equipment. The selection of shot blasting regimes for increasing the durability, reliability and safety of parts is justified. The given information allows expanding the possibilities of using shot blasting for road construction and mining equipment.
\end{abstract}

\section{Introduction}

Researchers have studied the damageability of parts of road-building machines during operation quite well, but there is not enough information about the damageability in the manufacturing process of parts.

The characteristic of the surface layer of a part includes many parameters, the basic one is a microgeometry of the surface, which determines the operational properties. According to Russian State Standard GOST 2789-73, the rough layer is determined by the parameters $R_{\max }, R_{a}, S_{m}, S, t_{p}$. The $R_{a}$ parameter is taken as the main roughness parameter. Step parameters determine the density of peaks and the uniformity of roughness in different directions through the ratio of longitudinal and transverse roughness

$$
K_{S}=\frac{S_{m I I}}{S_{m \perp}},
$$

where $S_{m I I}$ and $S_{m \perp}$ are average steps of microroughnesses along and across the direction of processing the part.

$K_{S}$ ratio is preferential. Anisotropy coefficient is currently used in the following form

$$
K_{R}=\frac{R_{a I I}}{R_{a \perp}},
$$

where $R_{a \mathrm{II}}$ and $R_{a \perp}$ are average sample $R_{a}$ values, measured along and across the processing direction of the part.

\footnotetext{
* Corresponding author: pushkarev-agn@mail.ru
} 
A number of other indicators not described in GOST 2789-73 are used in order to describe the surface characteristics of the part. In addition to these parameters, a number of other indicators are used to characterize the microgeometry of surface $[1,2]$. The contact interaction of the parts is simulated by modeling the roughness peaks and during operation it is described in [3, 4]. The ability to pump lubricant into the contact zone of parts is very important [5]. The problem of surface wettability and its connection with roughness can be attributed to the same area, while parts with roughness $R_{a}=2 \mu \mathrm{m}$ have better wettability with process fluids. The microrelief is closely related to the role of contact stresses during operation of the part [6].

The surface condition of the part (especially microgeometry) is very important in terms of qualitative criterion. Therefore, the microgeometry of the rough layer must be formed (regulated) for the quality of the part itself. Such formation is possible using surface plastic deformation of parts (SPD). SPD methods have diverse nature and purpose, which are determined by the general technological development [7]. The purposes of all SPD methods are divided into two types, which are hardening the surface of the part and building up the microrelief. For example, hydroimpulsive treatment allows obtaining $R_{a}$ of up to $0.32 \mu \mathrm{m}$ and increasing the surface microhardness up to $30 \%[8,9]$.

Literature data analysis shows that the whole SPD diversity cannot satisfy the possibility of obtaining an isotropic and wear-resistant microrelief of the surface of the part. Therefore, air shot blasting (ASB) and airless shot blasting (ALSB) are widely used, since these methods are productive, efficient, and controllable.

Building up the roughness of the part leads to a change in the friction conditions in the contact zone. The friction coefficient values were determined, and it was revealed that the friction in the contact zone during air shot blasting is increases up to $20 \%$. Studies (Figure 1) of air shot blasting have shown process controllability.

Microhardness, MPa

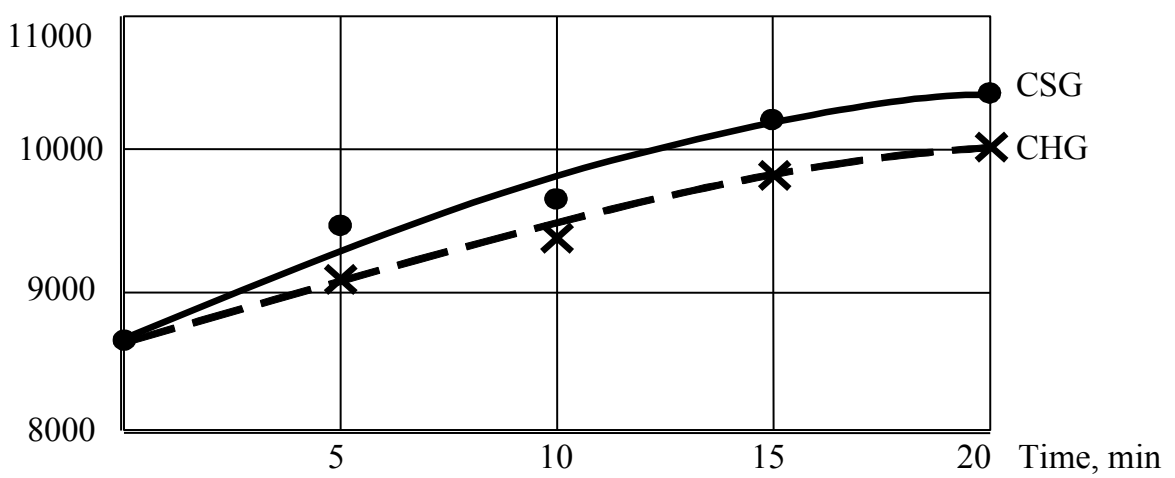

Fig. 1. Effect of scoring duration on surface microhardness.

\section{Methods}

Due to the multifactor and probabilistic nature of the shot blasting process, the processing modes are mainly chosen experimentally, by using selection or optimization. ASB was mainly considered during the study of the processing of parts using grit. ASB is less efficient and controllable than ALSB, which led to a private approach in researching this 
process through the search for individual targets. Thus, the need for a theoretical model, which allows using the full variety of ALSB details, becomes apparent.

An experiment was conducted on the Pangborn $310 \mathrm{MR}$ installation (Italy) in order to study the airless shot blasting treatment of hardened parts. CHG 1.5 grits were used, samples were made of structural steel with a diameter from 40 to $43 \mathrm{~mm}$ with heat treatment to a hardness of $65 . .70$ HRC.

The parameters of strain hardening are important for the operation of the parts of roadbuilding machines, which include the depth $h_{s}$ and the degree of hardening $H$. These parameters were determined by measuring the microhardness on the surface of oblique sections using the PMT-3 device, according to the martensitic component of the structure with a $0.05 \mathrm{~mm}$ step. Studying the process of airless shot blasting of rolls was carried out comprehensively, starting with the preparation of the surface of the part by grinding. The purpose of preparation by ALSB grinding is the clean surface without internal and external defects.

According to the above-mentioned, one of the important ALSB parameters is the ability to obtain isotropic surface roughness of the part. ALSB is highly productive and highly variable with a wide range of technological modes. Surface layer hardening and microdefects recovering occur during ALSB, and the microrelief itself can either be changed or re-formed. During processing, stress redistribution occurs in the surface layer (with a predominance of compressive stresses), which leads to a decrease in the probability of failure.

\section{Results}

The effect of ALSB modes on the qualitative surface layer characteristics of parts of roadbuilding and mining machines was studied. The purpose of the laboratory-industrial experiment was to determine the effect of ALSB modes on the qualitative surface layer characteristics of the hardened parts with the possibility of controlling the process. It was very important to know the condition of the part surface before ALSB for the research, which is reflected in table 1.

Table 1. Roughness parameters after grinding.

\begin{tabular}{|c|c|c|c|c|c|}
\hline $\begin{array}{c}\text { Sample } \\
\text { No }\end{array}$ & $R_{a}, \mathrm{~m}$ & $R_{z}, \mathrm{~m}$ & $R_{\max }, \mathrm{m}$ & $R_{p}, \mathrm{~m}$ & $S_{m}, \mathrm{~mm}$ \\
\hline 1.10 & 0.13 & 0.72 & 0.85 & 0.62 & 0.070 \\
\hline 3.15 & 0.37 & 2.02 & 2.36 & 1.15 & 0.076 \\
\hline 2.06 & 1.90 & 3.45 & 4.12 & 5.18 & 0.383 \\
\hline
\end{tabular}

The values of the roughness parameters do not represent a visual picture of the surface. Therefore, surface profilograms were recorded, examples of which are given in Figure 2. 
a)

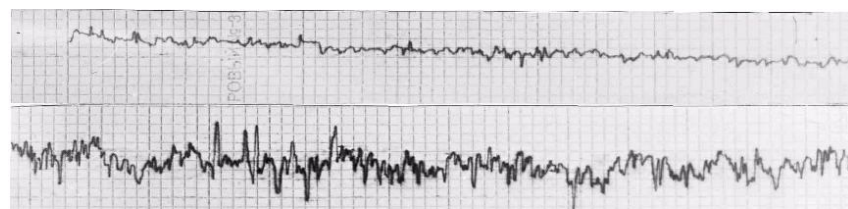

c)

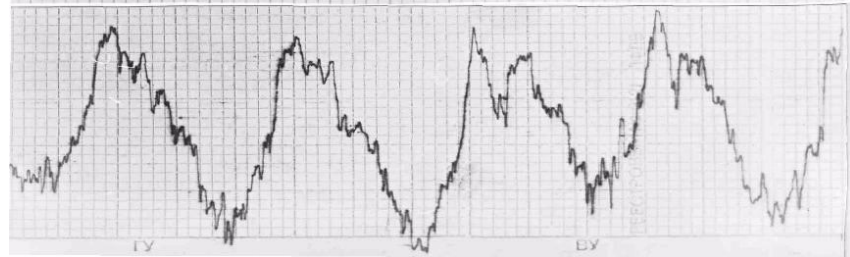

Fig. 2. Profilograms of following samples after grinding: samples 1.10(a), 3.15(b), 2.06(c), profilograms were taken from VU 5000 , GU 50 and $\mathrm{V}_{\text {tape }}=300 \mathrm{~mm} / \mathrm{min}$.

The results of studying the microhardness through ALSB (after grinding) are shown in Figure 3.

$\mathrm{H}, \mathrm{MPa}$

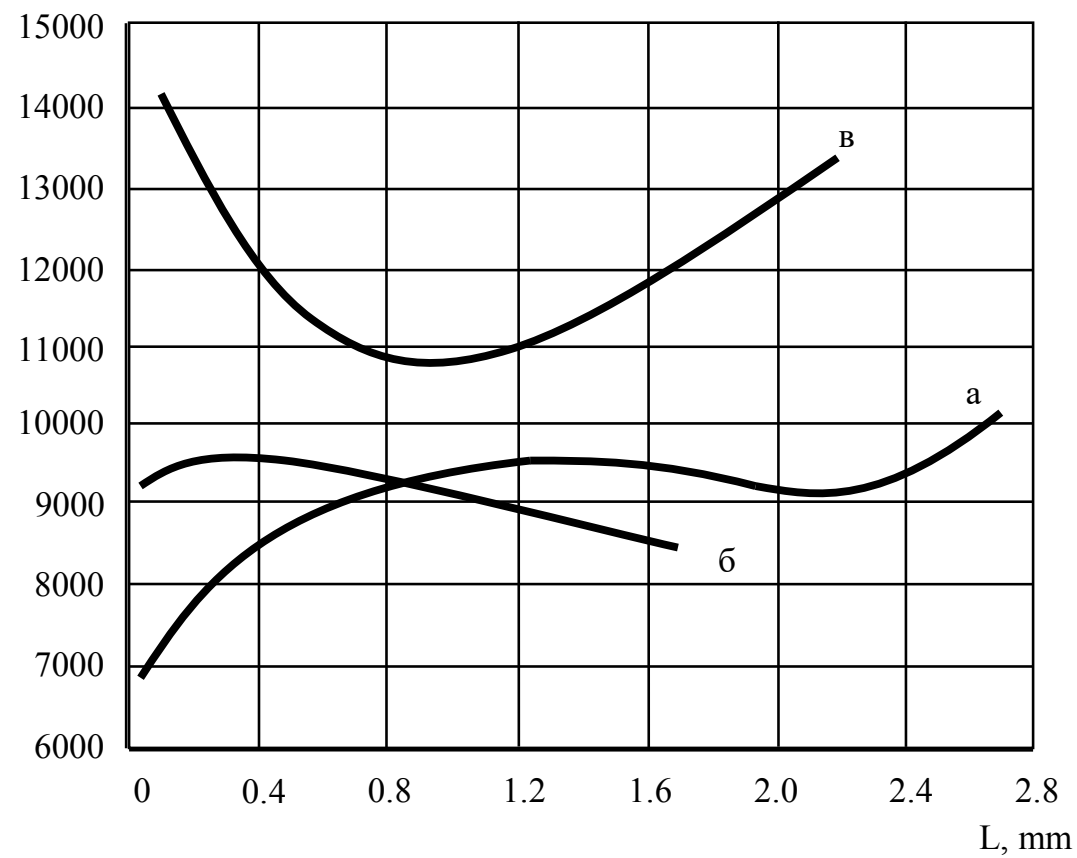

Fig. 3. The distribution of microhardness over the depth of the samples with different grindings, which are 3.15 (a), 1.10 (b), 2.06 (c).

\section{Discussion}

Processing the results led to an approximation of the correlations between microhardness and the distance from the surface. It is safe to say that microhardness measurements at a depth of $2 \ldots 3 \mathrm{~mm}$ showed its change within $8500 \ldots 11500 \mathrm{MPa}$. Sample 3.15 was burned during grinding, sample 1.10 was subjected to fine grinding, so its microhardness is 
uniform and distributed from the surface. Sample 2.06 was processed with increased efforts when grinding the surface.

Subsequent research came down to the shot blasting of parts. During ALSB, surface roughness, grit fraction, grit speed and the number of passes varied. The results are summarized in Table 2.

Table 2. The effect of ALSB factors on roughness.

\begin{tabular}{|c|c|c|c|c|c|c|c|c|c|c|c|c|c|}
\hline \multirow{2}{*}{ 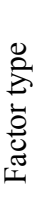 } & \multirow[b]{2}{*}{ № } & \multirow[b]{2}{*}{$\begin{array}{l}\text { Preliminary } \\
\text { roughness, } \\
\mathrm{R}_{\mathrm{a}}^{\mathrm{n}}, \mu \mathrm{m}\end{array}$} & \multicolumn{4}{|c|}{ ALSB modes } & \multicolumn{5}{|c|}{$\begin{array}{c}\text { Roughness parameters after } \\
\text { DME }\end{array}$} & \multirow{2}{*}{$\begin{array}{c}\text { Strain- } \\
\text { hardening } \\
\text { lepth, } \mathrm{h}_{\text {hard. }} \\
\mathrm{mm}\end{array}$} & \multirow[b]{2}{*}{$\begin{array}{l}\text { Hardenin } \\
\text { g degree, } \\
\quad \mathrm{N}\end{array}$} \\
\hline & & & \begin{tabular}{|l} 
Grit \\
fraction
\end{tabular} & $\begin{array}{l}\text { Rotor } \\
\text { speed, } \\
\text { min }^{-1}\end{array}$ & $\begin{array}{l}\text { Feed, } \\
\mathrm{m} / \mathrm{min}\end{array}$ & $\begin{array}{c}\text { Number } \\
\text { f double } \\
\text { passes }\end{array}$ & $\begin{array}{l}\mathrm{R}_{\mathrm{a}}, \\
\mu \mathrm{m}\end{array}$ & $\begin{array}{l}\mathrm{R}_{\mathrm{z}}, \\
\mu \mathrm{m}\end{array}$ & $\begin{array}{c}\mathrm{R}_{\max } \\
\mu \mathrm{m}\end{array}$ & $\begin{array}{l}\mathrm{R}_{\mathrm{p}} \\
\mu \mathrm{m}\end{array}$ & $\begin{array}{c}\mathrm{S}_{\mathrm{m}} \\
\mathrm{m}\end{array}$ & & \\
\hline \multirow{3}{*}{ 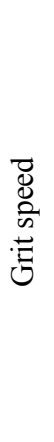 } & 1 & 0.15 & fine & 500 & 0.5 & 1 & 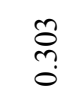 & $\hat{n}$ & $\stackrel{1}{0}$ & $\stackrel{0}{n}$ & Ỗ & 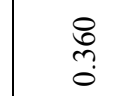 & $\stackrel{n}{n}$ \\
\hline & 2 & 0.15 & fine & 1000 & 0.5 & 1 & 吕 & $\stackrel{f}{+}$ & $\stackrel{+}{0}$ & $\stackrel{\infty}{\infty}$ & $\stackrel{+}{0}$ & 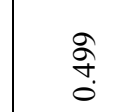 & 胥 \\
\hline & 3 & 0.15 & fine & 2100 & 0.5 & 1 & 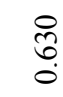 & $\tilde{n}$ & $\begin{array}{l}\infty \\
\infty \\
0\end{array}$ & $\infty$ & $\stackrel{n}{0}$ & $\begin{array}{ll}8 \\
: \\
0\end{array}$ & ڤై \\
\hline \multirow{3}{*}{ 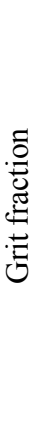 } & 4 & 0.15 & fine & 500 & 0.5 & 1 & 饣̂े & ஸे? & $\stackrel{\mathbb{N}}{0}$ & $\begin{array}{l}0 \\
n \\
0\end{array}$ & 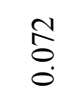 & $\begin{array}{l}8 \\
\text { ? } \\
0\end{array}$ & $\stackrel{n}{n}$ \\
\hline & 5 & 0.15 & fine & 500 & 0.5 & 1 & $\begin{array}{l}\infty \\
: \\
0 \\
0\end{array}$ & $\hat{\alpha}$ & $\begin{array}{l}\infty \\
\infty \\
i\end{array}$ & $\stackrel{\overbrace{}}{i}$ & $\stackrel{\widehat{N}}{\stackrel{0}{0}}$ & 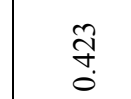 & 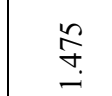 \\
\hline & 6 & 0.15 & fine & 500 & 0.5 & 1 & $\stackrel{n}{n}$ & $\stackrel{\infty}{\dot{m}}$ & 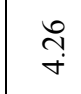 & $\stackrel{\infty}{\stackrel{+}{+}}$ & 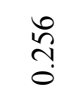 & $\begin{array}{l}\vec{\infty} \\
\infty \\
0\end{array}$ & $\stackrel{0}{\stackrel{1}{ }}$ \\
\hline \multirow{3}{*}{ 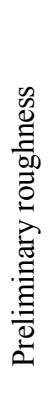 } & 7 & 0.15 & fine & 500 & 0.5 & 1 & $\begin{array}{l}\infty \\
\stackrel{\infty}{0} \\
0\end{array}$ & $\begin{array}{l}\infty \\
\infty \\
\infty\end{array}$ & $\stackrel{\infty}{\sigma}$ & $\stackrel{n}{n}$ & $\begin{array}{l}\infty \\
\infty \\
0 \\
0\end{array}$ & $\stackrel{2}{\stackrel{2}{1}}$ & 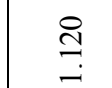 \\
\hline & 8 & 0.50 & fine & 500 & 0.5 & 1 & $\begin{array}{l}\text { to } \\
\stackrel{0}{0} \\
0\end{array}$ & $\stackrel{\circ}{\sim}$ & $\begin{array}{l}\hat{b} \\
\text { ì }\end{array}$ & $\stackrel{8}{8}$ & 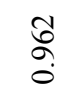 & 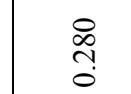 & $\stackrel{ }{\stackrel{ }{ }}$ \\
\hline & 9 & 1.90 & fine & 500 & 0.5 & 1 & $\stackrel{\text { }}{\circ}$ & $\ddot{n}$ & $\stackrel{f}{\stackrel{f}{r}}$ & $\begin{array}{l}\tilde{\sigma} \\
\stackrel{i}{ }\end{array}$ & $\stackrel{n}{2}$ & $\stackrel{\stackrel{\Im}{~}}{\stackrel{0}{\circ}}$ & ?ి \\
\hline
\end{tabular}




\begin{tabular}{|c|c|c|c|c|c|c|c|c|c|c|c|c|c|}
\hline \multirow{9}{*}{ 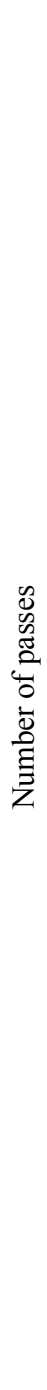 } & 10 & 0.15 & fine & 350 & 1.0 & 1 & $\begin{array}{l}\tilde{\rho} \\
\tilde{n} \\
0\end{array}$ & ஸे & $\stackrel{\mathbb{O}}{0}$ & $\begin{array}{l}0 \\
\stackrel{2}{0}\end{array}$ & $\begin{array}{l}\mathbb{N} \\
0 \\
0\end{array}$ & $\begin{array}{l}8 \\
\substack{0 \\
0}\end{array}$ & $\stackrel{n}{\stackrel{n}{n}}$ \\
\hline & 11 & 0.50 & fine & 350 & 1.0 & 1 & $\begin{array}{l}\infty \\
\stackrel{\infty}{0}\end{array}$ & $\stackrel{\circ}{+}$ & $\stackrel{\mathbb{R}}{\stackrel{0}{0}}$ & $\stackrel{0}{0}$ & $\begin{array}{l}\text { : } \\
0 \\
0\end{array}$ & $\begin{array}{c}8 \\
\text { ले } \\
0\end{array}$ & 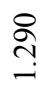 \\
\hline & 12 & 1.90 & fine & 350 & 1.0 & 1 & $\vec{N}$ & $\stackrel{q}{+}$ & $\stackrel{N}{\stackrel{0}{0}}$ & $\begin{array}{l}\infty \\
\infty \\
0\end{array}$ & oे & $\begin{array}{l}\infty \\
\stackrel{0}{n} \\
?\end{array}$ & ণે \\
\hline & 13 & 0.15 & fine & 350 & 1.0 & 2 & $\begin{array}{l}\tilde{\infty} \\
\stackrel{\infty}{0} \\
0\end{array}$ & $\stackrel{\text { I }}{0}$ & $\overrightarrow{0}$ & $\stackrel{\infty}{\infty}$ & छे & 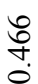 & $\stackrel{\ominus}{\underset{\sigma}{\sigma}}$ \\
\hline & 14 & 0.50 & fine & 350 & 1.0 & 2 & \begin{tabular}{l}
8 \\
\multirow{+}{0}{} \\
0
\end{tabular} & 웅. & $\overrightarrow{0}$ & $\stackrel{2}{6}$ & $\begin{array}{l}n \\
0 \\
0\end{array}$ & $\begin{array}{l}\stackrel{+}{+} \\
\stackrel{+}{0}\end{array}$ & $\stackrel{n}{n}$ \\
\hline & 15 & 1.90 & fine & 350 & 1.0 & 2 & $\begin{array}{l}\text { ָे } \\
\text { ?ִ }\end{array}$ & $\stackrel{0}{ \pm}$ & $\stackrel{?}{\circ}$ & $\stackrel{n}{\stackrel{o}{o}}$ & $\begin{array}{l}0 \\
0 \\
0\end{array}$ & $\begin{array}{c}\text { ్ֶర } \\
\stackrel{0}{0}\end{array}$ & 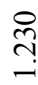 \\
\hline & 16 & 0.15 & fine & 350 & 1.0 & 3 & $\begin{array}{l}\text { ? } \\
\text { ? }\end{array}$ & $\stackrel{n}{n}$ & $\begin{array}{l}\hat{\sigma} \\
\dot{0}\end{array}$ & $\begin{array}{l}\stackrel{0}{n} \\
\stackrel{2}{0}\end{array}$ & $\begin{array}{l}\stackrel{2}{0} \\
0 \\
0\end{array}$ & $\begin{array}{l}\text { : } \\
\text { ?n }\end{array}$ & $\stackrel{\tilde{D}}{\stackrel{n}{n}}$ \\
\hline & 17 & 0.50 & fine & 350 & 1.0 & 3 & $\begin{array}{l}\hat{o} \\
\text { o } \\
0\end{array}$ & $\stackrel{\text { fo }}{\circ}$ & $\overrightarrow{0}$ & $\begin{array}{l}n \\
0 \\
0\end{array}$ & $\begin{array}{l}\tilde{o} \\
\stackrel{0}{0}\end{array}$ & 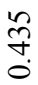 & $\stackrel{8}{8}$ \\
\hline & 18 & 1.90 & fine & 350 & 1.0 & 3 & $\underset{n}{?}$ & $\stackrel{n}{n}$ & $\begin{array}{l}\stackrel{8}{0} \\
\stackrel{0}{0}\end{array}$ & $\stackrel{g}{\stackrel{f}{0}}$ & $\stackrel{\substack{0 \\
0}}{0}$ & 司 & 요 \\
\hline
\end{tabular}

A crucial mode affecting the parameters of the surface layer after ALSB is the grit speed, as can be seen from the graph in Figure 4. With increasing speed, the roughness parameters increase, since the penetration depth into the surface of the part increases with increasing grit speed. 


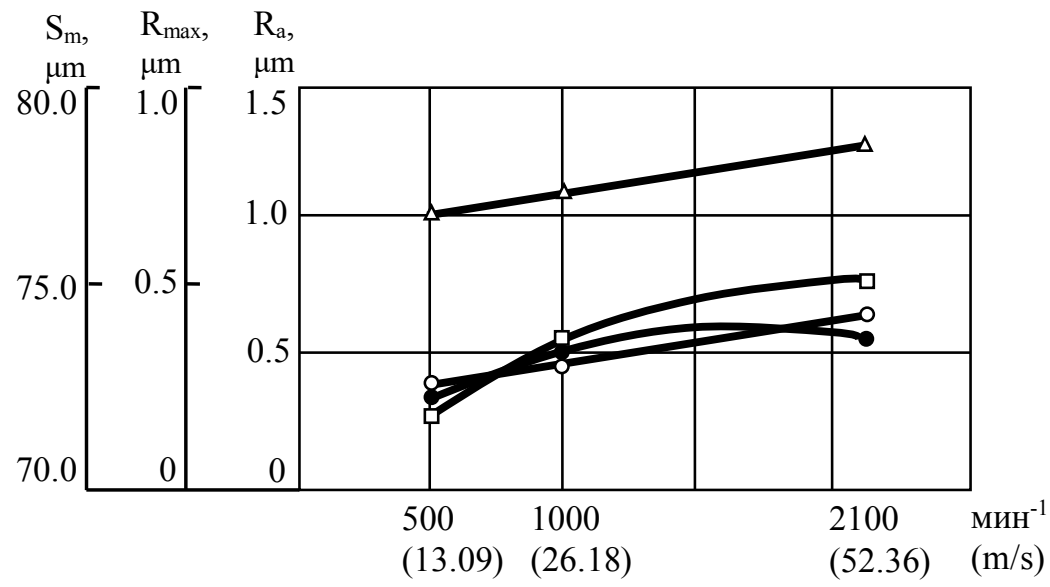

O- $\mathrm{R}_{\mathrm{a}}, \mu \mathrm{m} \quad \Delta-\mathrm{R}_{\max }, \mu \mathrm{m} \quad \square-\mathrm{S}_{\mathrm{m}}, \mathrm{mm}$;

- - graph of the V. L. Mazur equation

Fig. 4. The correlation between roughness parameters and the grit speed.

The result of the experiment is clearly visible on profilograms in Figure 5.

a)

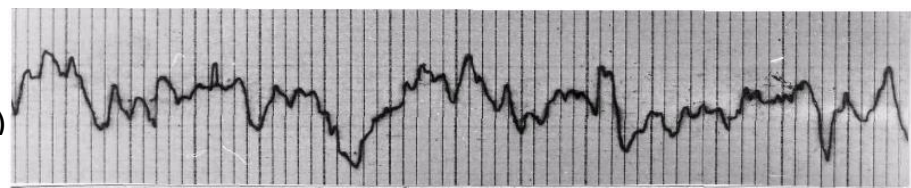

b)

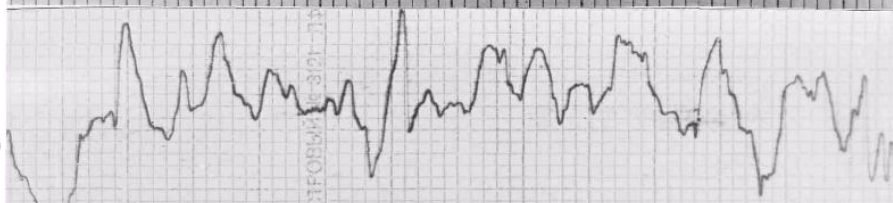

c)

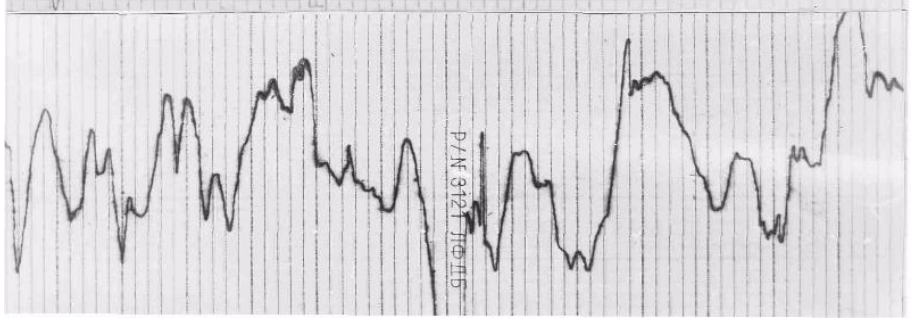

Fig. 5. Profilograms of samples with dependences on grit speed: $13.09 \mathrm{~m} / \mathrm{s}(\mathrm{a}), 26.18 \mathrm{~m} / \mathrm{s}$ (b), 52.36 $\mathrm{m} / \mathrm{s}$ (c) VU5000, GU 100.

In addition to speed, an equally important factor affecting the roughness of a part during ALBS is the grit fraction, which is experimentally demonstrated (Figure 6). 
$\mathrm{S}_{\mathrm{m}}, \quad \mathrm{R}_{\max }, \quad \mathrm{R}_{\mathrm{a}}$,

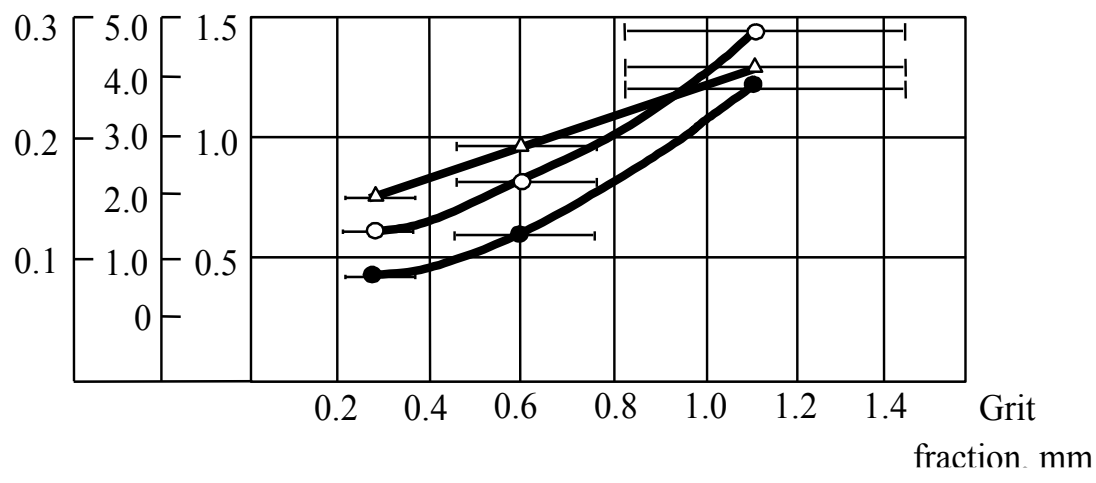

$\bigcirc-\mathrm{R}_{\mathrm{a}}, \mu \mathrm{m} ; \quad \Delta-\mathrm{R}_{\max }, \mu \mathrm{m} ; \quad-\mathrm{S}_{\mathrm{m}}, \mathrm{mm}$

Fig. 6. The dependence of the roughness parameters on the grit fraction.

With an increase in grit fraction, the roughness increases, since the increase in size leads to the grit mass growth. Accordingly, kinetic energy increases. The microprofile shape can be seen on the profilograms in Figure 7.

a)

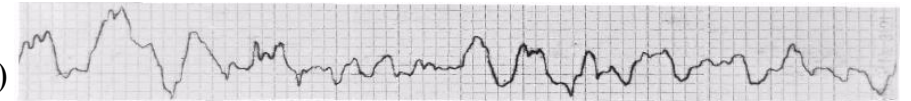

b)

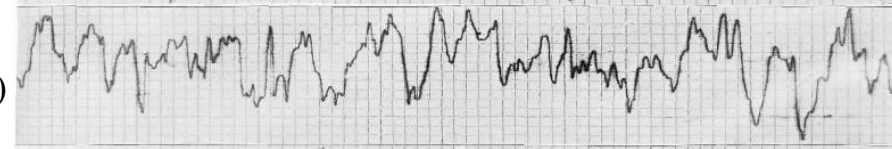

c)

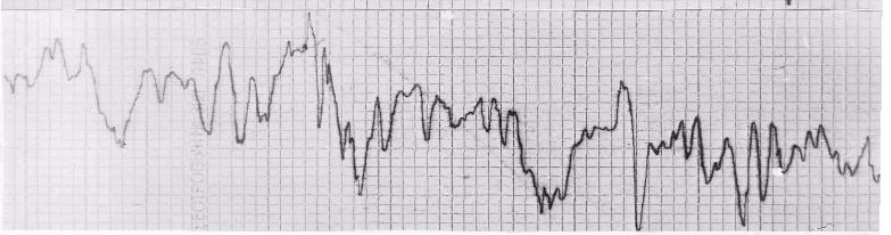

Fig. 7. Profilograms of samples depending on the grit fraction: $0.2 \ldots 0.4 \mathrm{~mm}(\mathrm{a}), 0.4 \ldots 0.8 \mathrm{~mm}$ (b), $0.8 \ldots 1.5 \mathrm{~mm}$ (c) VU5000, GU50.

Another important factor affecting the ALSB results of the part is the roughness of the initial surface. The result of an experiment conducted to determine the initial roughness effect on the roughness after ALSB is presented in Figure 8. The experiment considers various grit fractions and different number of passes. 
$R_{a}{ }^{D}, \mu \mathrm{m}$

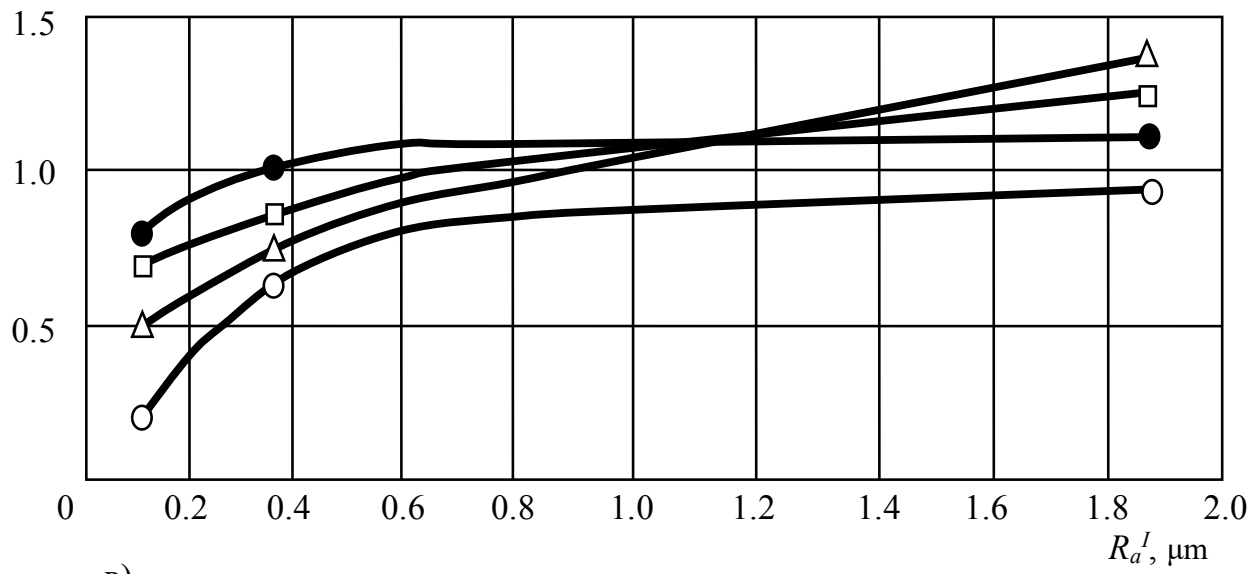

B)

- grit $0.2 \ldots 0.4 \mathrm{MM}, \mathrm{n}=500 \mathrm{~min}^{-1}, 1$ double pass;

$\triangle$ - grit $0.4 \ldots 0.8 \mathrm{Mm}, \mathrm{n}=350 \mathrm{~min}^{-1}, 1$ double pass;

$\square$ - grit $0.4 \ldots 0.8 \mathrm{Mm}, \mathrm{n}=350 \mathrm{~min}^{-1}, 2$ double passes;

- grit $0.4 \ldots 0.8 \mathrm{MM}, \mathrm{n}=350 \mathrm{~min}^{-1}, 3$ double passes.

Fig. 8. The effect of the initial roughness on the roughness after ALBS by the parameter $R a$.

The parameter $R_{a}$ does not provide sufficient information about the microrelief from the perspective of operational properties of the part surface. Therefore, the correlations $S_{m}$ between the initial roughness and roughness after ALBS were determined (Figure 9).

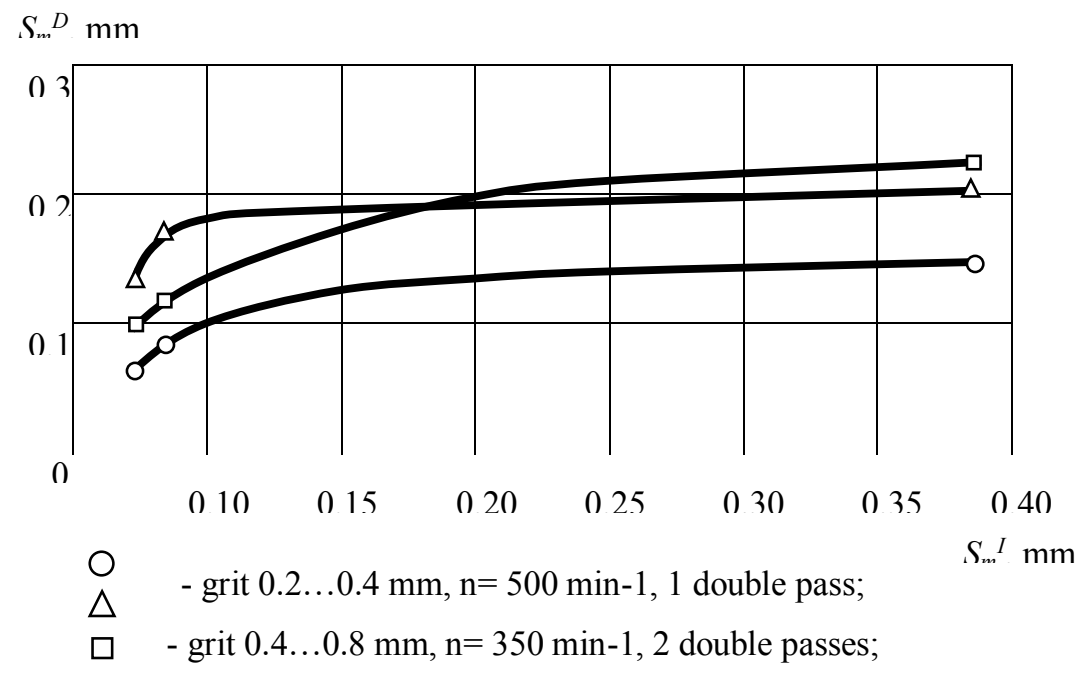

Fig. 9. Effect of the initial roughness on the roughness after ALSB according to the $S_{m}$ parameter.

The profilograms presented in Figure 10 show the micro-relief before and after the ALSB of each sample, when treated with fine grit $(0.2 \ldots 0.4 \mathrm{~mm})$ at a speed of $500 \mathrm{~min}^{-1}$ rotor in 1 double pass. 
a)

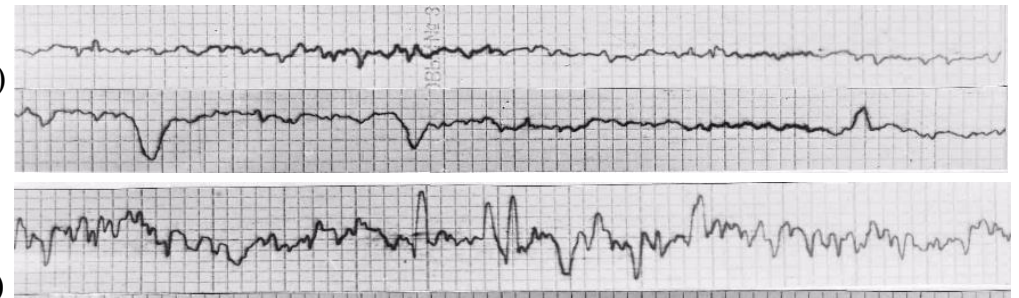

b)

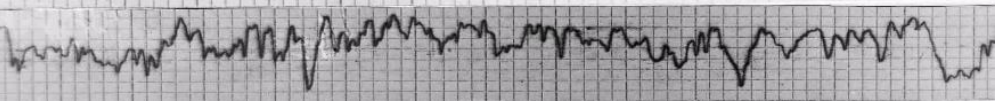

c)

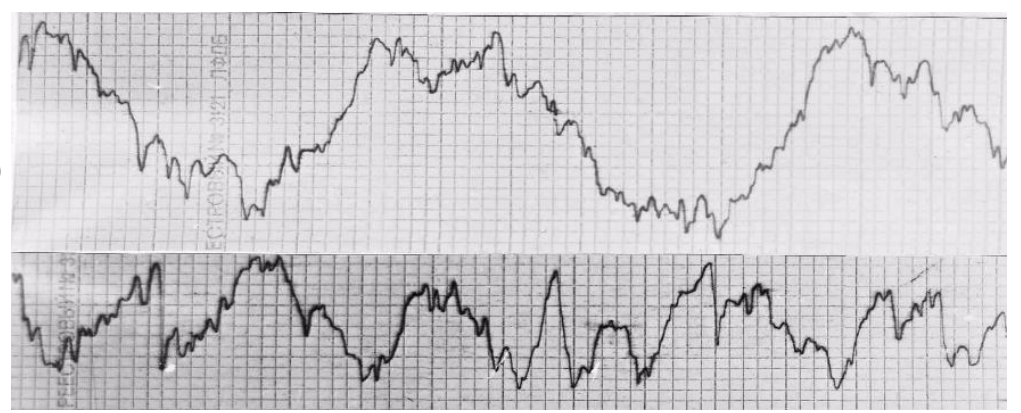

Fig. 10. Profilograms of samples before and after ALSB: 1st series (a), 2nd series (b), 3rd series (c) VU 5000, GU 100.

The formation of the microrelief is affected by such a technological parameter as the number of grit shots per unit area, which is determined by the number of passes of the part under the shot plume, which is demonstrated in the experimental results in Figure 11.

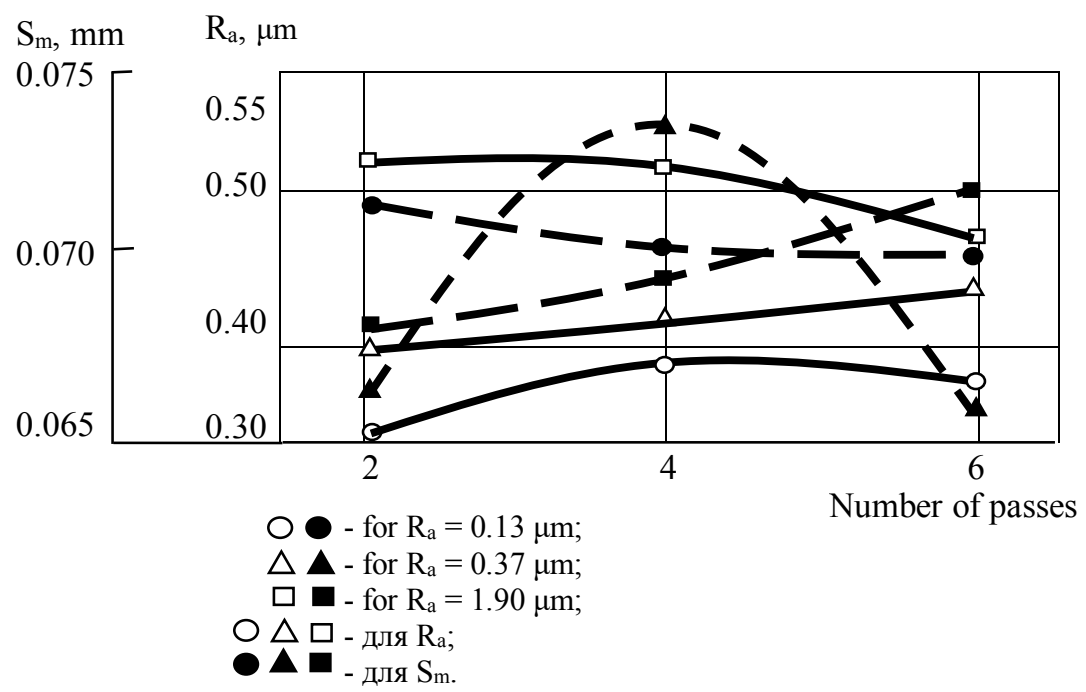

Fig. 11. The effect of the number of passes with ALSB on the roughness parameters.

According to the parameter $R_{a}$, the initial high-quality surface deteriorates with an increase in the number of passes, and the rough surface becomes better. It is explained by the fact that the ALSB forms its microrelief. The decrease in the parameter $S_{m}$ can be explained the same way, as can be seen on the profilograms (Figure 12). 
a)

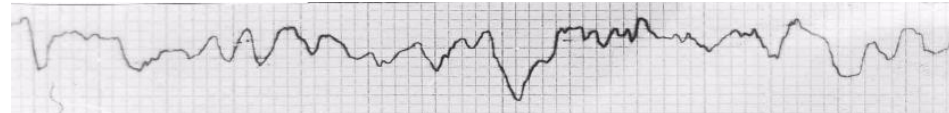

b)

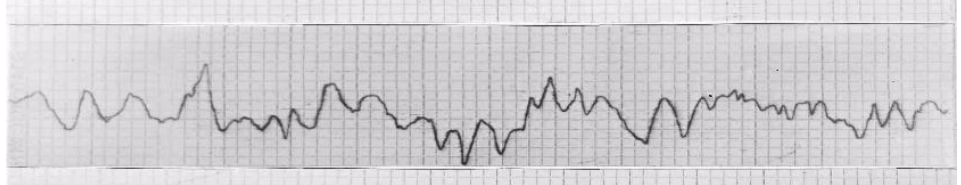

c)

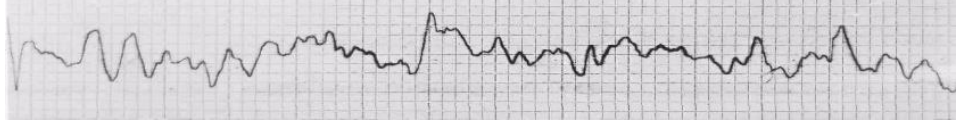

Fig. 12. Profilograms of samples with initial roughness $R_{a}=0.13 \mu \mathrm{m}$, depending on the number of passes: 1 double pass (a), 2 double pass (b), 3 double pass (c) WU 5000 GU 100.

Table 2 also shows the experimental result of the influence of ALSB on the size of the hardening and its depth, a visual representation of which is shown in Figures 13 and 14.

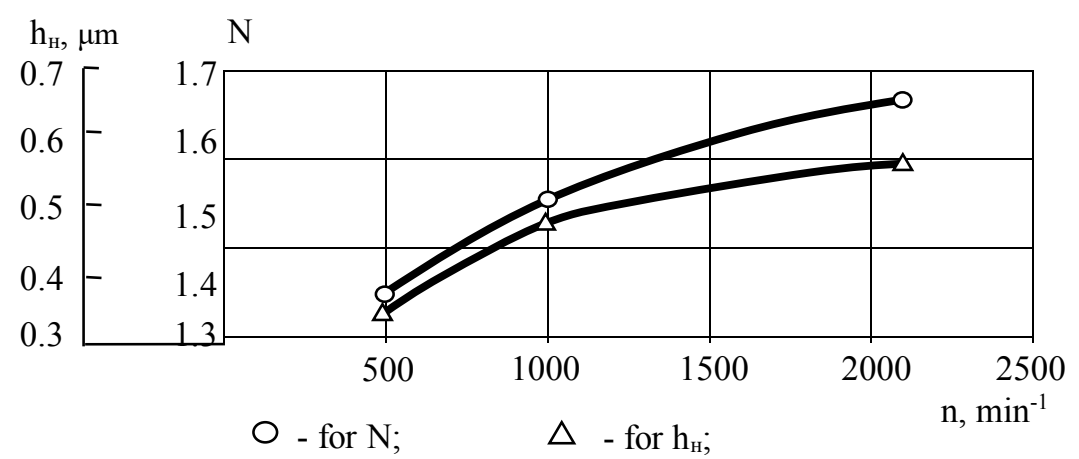

Fig. 13. The effect of grit speed on the depth $h_{H}$ and the degree of hardening $N$ of the surface layer. 


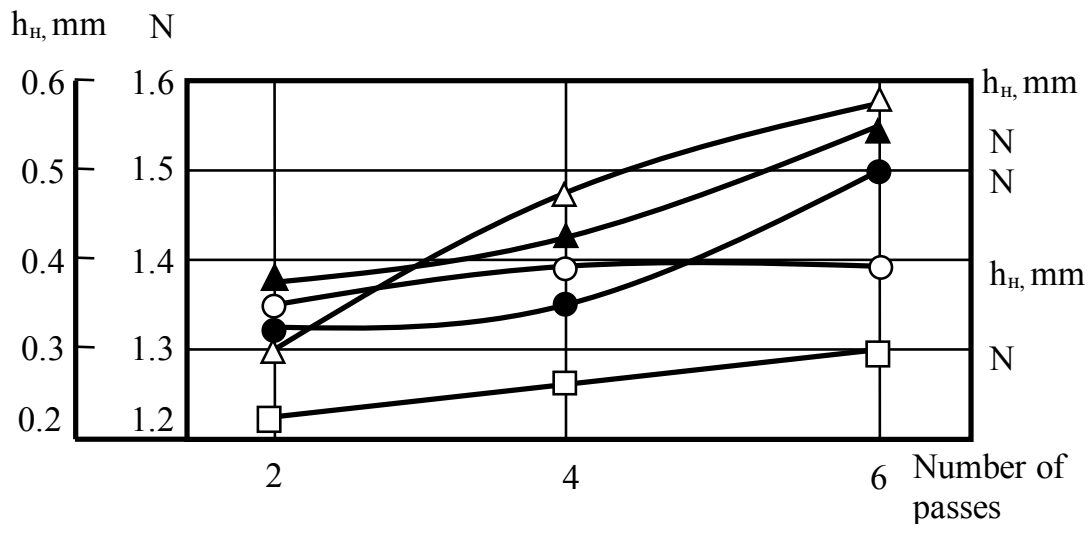

$\bigcirc \quad$ - with $\mathrm{R}_{\mathrm{a}}=0.34 \mu \mathrm{m} ; \quad \Delta \triangle$ - with $\mathrm{R}_{\mathrm{a}}=0.17 \mu \mathrm{m}$;

$\square$ - according to L.G. Odintsova [7]

Fig. 14. Effect of the number of passes (processing time) on the depth $h_{H}$ and the degree of hardening $N$ during ALSB.

\section{Conclusion}

The study and analysis of ALSB allowed concluding that it is possible to achieve various types of microrelief by varying the ALSB modes. It depends on the operating conditions of parts of road-building and mining machines. Consequently, due to the high variability of the ALSB modes and the capabilities of the technology, it is possible to increase the durability, reliability and safety of machines. The implementation of the above-mentioned developments has improved the quality of the parts being restored.

\section{References}

1. A.P. Grudev, Ju.V. Zil'berg, V.T. Tilik, Trenie $i$ smazki pri obrabotke metallov davleniem: Spravochnik (312, Metallurgija, 1982)

2. A.G. Suslov, Tehnologicheskoe obespechenie parametrov sostojanija poverhnostnogo sloja detalej (208, Mashinostroenie, Moscow, 1987)

3. N.B. Demkin, Kontaktirovanie sherohovatyh poverhnostej (227, Nauka, Moscow, 1970)

4. A.M. Sulima, V.A. Shulov, Ju.D. Jagodkin, Poverhnostnyj sloj i jekspluatacionnye svojstva detalej mashin (Mashinostroenie, 240, 1988)

5. V.V. Harlamov, G.L. Himich, Trenie i iznos, 10, №16 54-65 (1989)

6. V. Prager, Jo. Hodzh, Teorija ideal'no-plasticheskih tel. (338, MNIL, Moscow, 1956)

7. L.G. Odincov, Uprochnenie $i$ otdelka detalej poverhnostnym plasticheskim deformirovaniem: Spravochnik. (328, Mashinostroenie, Moscow, 1987)

8. Ju.M. Kulakov, V.A. Hrul'kov, Otdelochno-zachistnaja obrabotka detalej (216, Mashinostroenie, Moscow, 1979)

9. L.A. Hvorostuhin, S.V. Shishkin, I.P. Kovalev, Povyshenie nesushhej sposobnosti detalej mashin poverhnostnym uprochneniem (144, Mashinostroenie, 1988)

10. E. Kurakina, S. Evtyukov, Architecture and Engineering, 2(3), 7-9 (2017) 